\title{
Biochemical methane potential of raw and pre-treated meat-processing wastes
}

\author{
A.J. Cavaleiro ${ }^{\text {a,* }}$, T. Ferreira ${ }^{\text {a,b }}$, F. Pereira ${ }^{\text {a }}$, G. Tommaso ${ }^{c}$, M.M. Alves ${ }^{\text {a }}$ \\ a Institute for Biotechnology and Bioengineering, Centre of Biological Engineering, University of Minho, Campus de Gualtar, 4710-057 Braga, Portugal

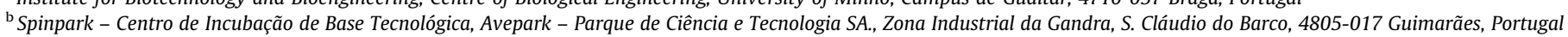 \\ ${ }^{\mathrm{C}}$ Laboratory of Environmental Biotechnology, Department of Food Engineering, School of Animal Science and Food Engineering, University of São Paulo, Pirassununga, Brazil
}

\section{H I G H L I G H T S}

- Biochemical methane potential (BMP) of pre-treated greaves and rinds were studied.

- BMP of rinds was improved $25 \%$ by exposure to $70{ }^{\circ} \mathrm{C}$ for $24 \mathrm{~h}$.

- Incomplete hydrolysis of rinds caused inhibition of methanogens in the BMP assays.

- For greaves, hydrolysis was the limiting step even after the applied pre-treatments.

\section{A R T I C L E I N F O}

\section{Article history:}

Received 25 June 2012

Received in revised form 17 November 2012

Accepted 19 November 2012

Available online 2 December 2012

\section{Keywords:}

Pre-treatments

Hydrolysis

Biochemical methane potential

Meat-processing wastes

\begin{abstract}
A B S T R A C T
Raw and pre-treated greaves and rinds, two meat-processing wastes, were assessed for biochemical methane potential (BMP). Combinations of temperature $\left(25,55,70\right.$ and $\left.120^{\circ} \mathrm{C}\right), \mathrm{NaOH}\left(0.3 \mathrm{~g} \mathrm{~g}^{-1}\right.$ waste volatile solids) and lipase from Candida rugosa $\left(10 \mathrm{U} \mathrm{g}^{-1}\right.$ fat) were applied to promote wastes hydrolysis, and the effect on BMP was evaluated. COD solubilisation was higher (66\% for greaves; $55 \%$ for rinds) when greaves were pre-treated with $\mathrm{NaOH}$ at $55^{\circ} \mathrm{C}$ and lipase was added to rinds after autoclaving. Maximum fat hydrolysis (52-54\%) resulted from $\mathrm{NaOH}$ addition, at $55^{\circ} \mathrm{C}$ for greaves and $25^{\circ} \mathrm{C}$ for rinds. BMP of raw greaves and rinds was $707 \pm 46$ and $756 \pm 56 \mathrm{~L} \mathrm{CH}_{4}$ (at standard temperature and pressure) $\mathrm{kg}^{-1} \mathrm{VS}$, respectively. BMP of rinds improved $25 \%$ by exposure to $70^{\circ} \mathrm{C}$; all other strategies tested had no positive effect on BMP of both wastes, and anaerobic biodegradability was even reduced by the combined action of base and temperature.
\end{abstract}

(c) 2012 Elsevier Ltd. All rights reserved.

\section{Introduction}

Slaughterhouses and meat processing industries generate large amounts of wastes and by-products, e.g. carcasses, feet, offal, hides, bones and blood, corresponding to $40-50 \%$ of the total animal weight slaughtered (Cuadros et al., 2011; FAOSTAT, 2012). Anaerobic digestion of organic wastes is a highly sustainable process, since it combines waste treatment with energy production in the form of biogas and nutrients recycling. Animal wastes are typically rich in fats and proteins (Salminen and Rintala, 2002), therefore representing a good substrate for biogas production. However, the conversion of these complex particulate materials to methane in anaerobic digesters is frequently limited by the hydrolysis step (Masse et al., 2003; Vavilin et al., 1996). Efficient hydrolysis is crucial to make complex substrates accessible to anaerobic bacteria and ultimately optimize methane production.

\footnotetext{
* Corresponding author. Tel.: +351 253604 400; fax: +351 253678986.

E-mail addresses: acavaleiro@deb.uminho.pt (A.J. Cavaleiro), tommaso@usp.br (G. Tommaso), madalena.alves@deb.uminho.pt (M.M. Alves).
}

Several pre-treatment techniques have been applied to enhance hydrolysis and anaerobic biodegradability of organic wastes (Cammarota and Freire, 2006; Carrère et al., 2010; Costa et al., 2012; Hejnfelt and Angelidaki, 2009; Luste et al., 2009). Physical treatments such as high temperature, microwaves, ultrasounds, grinding and maceration destroy aggregated particles, decrease particles size and disrupt cell structure. The molecular structure of the material can be changed through the addition of acids or bases, or through the action of enzyme-producing microorganisms (bioaugmentation) or enzyme preparations. The majority of the studies have been focused on pre-treating waste activated sludge or wastewaters (Bougrier et al., 2008; Cammarota and Freire, 2006; Carrère et al., 2010; Masse et al., 2003; Valladão et al., 2007; Zhang and Jahng, 2010), and only few authors tested this approach on animal wastes (Table 1 ).

In most cases the hydrolysis of the wastes is not complete and only partial solubilisation of the materials or particle size reduction is achieved. Additionally, methane production from the hydrolysates is not always higher than that obtained from untreated wastes, and in some cases it even decreases (Costa et al., 2012; 
Table 1

Examples of reported studies on pre-treatment and anaerobic digestion of slaughterhouse and meat-processing wastes.

\begin{tabular}{|c|c|c|c|}
\hline Pre-treatment conditions applied & Wastes & Anaerobic digestion conditions & Reference \\
\hline \multicolumn{4}{|l|}{ Thermal } \\
\hline $70^{\circ} \mathrm{C}, 60 \mathrm{~min}$ & DTC, DSW, DAF, GTS & Batch, $35^{\circ} \mathrm{C}$, substrate:inoculum $1: 1$ & Luste et al. (2009) \\
\hline $70^{\circ} \mathrm{C}, 60 \mathrm{~min}$ & MPW & Batch, $37^{\circ} \mathrm{C}$ and $55^{\circ} \mathrm{C}$ & Hejnfelt and Angelidaki (2009) \\
\hline $133^{\circ} \mathrm{C}, P>3 \mathrm{bar}, 20 \mathrm{~min}$ & MPW & Batch, $37^{\circ} \mathrm{C}$ and $55^{\circ} \mathrm{C}$ & Hejnfelt and Angelidaki (2009) \\
\hline $\begin{array}{l}133^{\circ} \mathrm{C}, P>3 \mathrm{bar}, 20 \mathrm{~min} \\
\text { Ultrasound }\end{array}$ & SHW & Semi-continuously fed CSTR & Cuetos et al. (2010) \\
\hline $\begin{array}{l}5600 \pm 300 \mathrm{~kJ} \mathrm{~kg}^{-1} \mathrm{TS}, 25^{\circ} \mathrm{C} \\
\text { Alkaline }\end{array}$ & DTC, DSW, DAF, GTS & Batch, $35^{\circ} \mathrm{C}$, substrate:inoculum $1: 1$ & Luste et al. (2009) \\
\hline $\begin{array}{l}\mathrm{NaOH} 2 \mathrm{M}(6-14 \%), 4 \mathrm{~h} \\
\mathrm{NaOH} 50-100 \mathrm{~g} \mathrm{~kg}^{-1} \mathrm{VS} \\
\text { Acid }\end{array}$ & $\begin{array}{l}\text { DTC, DSW, DAF, GTS } \\
\text { MPW }\end{array}$ & $\begin{array}{l}\text { Batch, } 35^{\circ} \mathrm{C} \text {, substrate:inoculum } 1: 1 \\
\text { Batch, } 37^{\circ} \mathrm{C} \text { and } 55^{\circ} \mathrm{C}\end{array}$ & $\begin{array}{l}\text { Luste et al. (2009) } \\
\text { Hejnfelt and Angelidaki (2009) }\end{array}$ \\
\hline $\begin{array}{l}\mathrm{HCl} 6 \mathrm{M}(2-8 \%), 4 \mathrm{~h} \\
\text { Termo-chemical }\end{array}$ & DTC, DSW, DAF, GTS & Batch, $35^{\circ} \mathrm{C}$, substrate:inoculum 1:1 & Luste et al. (2009) \\
\hline $\begin{array}{l}\mathrm{NaOH}, 0.04 \mathrm{~mol} \mathrm{~g}^{-1} \mathrm{COD}, 60^{\circ} \mathrm{C}, 30 \mathrm{~min} \\
\mathrm{NaOH}, 0.156 \mathrm{~g} \mathrm{~g}^{-1} \mathrm{VS}, 60-150^{\circ} \mathrm{C}, 3 \mathrm{~h} \\
\text { Bacterial product }\end{array}$ & $\begin{array}{l}\text { DAF, FF } \\
\text { DAF, FF }\end{array}$ & $\begin{array}{l}\text { Fed-batch reactors, } 0.1-0.2 \mathrm{~g} \text { COD g- } 1 \mathrm{VS}, 35^{\circ} \mathrm{C} \text { and } 55^{\circ} \mathrm{C} \\
\text { Fed-batch reactors, } 35^{\circ} \mathrm{C}, 1-5 \mathrm{~g} \text { COD L- } 1\end{array}$ & $\begin{array}{l}\text { Battimelli et al. (2009) } \\
\text { Battimelli et al. (2010) }\end{array}$ \\
\hline $\begin{array}{l}\text { Liquid certizyme } 5 \mathrm{TM}, 60 \mathrm{mg} \mathrm{L}^{-1}, 24 \mathrm{~h}, 25^{\circ} \mathrm{C} \\
\text { Enzymatic }\end{array}$ & DTC, DSW, DAF & Batch, $35^{\circ} \mathrm{C}$, substrate:inoculum 1:1 & Luste et al. (2009) \\
\hline Pancreatic lipase, $250 \mathrm{mg}$ enzyme $\mathrm{L}^{-1}, 5.5 \mathrm{~h}, 25^{\circ} \mathrm{C}$ & PFPSW & Anaerobic sequencing batch reactor, $25^{\circ} \mathrm{C}$ & Masse et al. (2003) \\
\hline
\end{tabular}

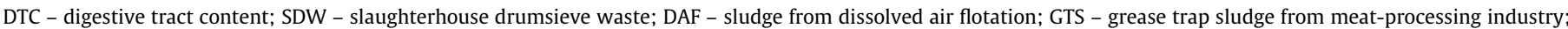

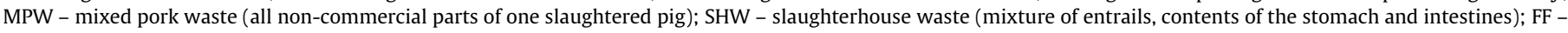
flesh fats from animal carcasses; PFPSW - pork fat particles in slaughterhouse wastewater. CSTR - continuously stirred tank reactor.

Cuetos et al., 2010; Hejnfelt and Angelidaki, 2009; Luste et al., 2009). For example, none of the five pre-treatments tested by Luste et al. (2009) was able to improve the biochemical methane potential (BMP) of slaughterhouse drumsieve waste, despite a $26-76 \%$ increase in the soluble chemical oxygen demand (COD) measured after pre-treatments (Table 1), and the BMP values obtained for the pre-treated materials were actually 20-39\% lower than those of the untreated waste $\left(400 \mathrm{~m}^{3} \mathrm{CH}_{4} \mathrm{t}^{-1} \mathrm{VS}\right)$. Cuetos et al. (2010) also reported a lower biogas production $\left(2.9 \mathrm{Lday}^{-1}\right)$ during the digestion of slaughterhouse waste (SHW) previously submitted to the combined action of temperature and pressure $\left(133^{\circ} \mathrm{C}\right.$, $>3 \mathrm{bar}, 20 \mathrm{~min}$ ), than during digestion of the untreated SHW (3.2 $\mathrm{L} \mathrm{day}^{-1}$ ) in continuously stirred tank reactors (CSTR).

This reduced methane production is probably caused by inhibitory compounds, such as long-chain fatty acids (LCFA) and ammonia, produced during the hydrolysis of lipids and proteins (Alves et al., 2009; Salminen and Rintala, 2002). LCFA tend to adsorb onto the surface of the microbial cell wall, possibly hindering the transfer of substrates and products (Pereira et al., 2005). Although these effects are not irreversible, long periods of time are frequently needed for complete conversion of these compounds to methane (Alves et al., 2009; Cavaleiro et al., 2008). The toxicity of ammonia is related to changes in the intracellular $\mathrm{pH}$ caused by the non-ionized form $\mathrm{NH}_{3}$ that easily penetrates the microbial cell membrane. Moreover, ammonia inhibition of enzymes involved in methane formation has also been suggested (Kadam and Boone, 1996).

Optimal methane production from meat-processing wastes is still challenging. Improvement of the hydrolysis step while preventing inhibition of the microbial communities by the hydrolysis products is required. Physical separation of the hydrolysis step from the anaerobic conversion of the hydrolysates to methane, in a two-phase process, can possibly circumvent this inhibition and contribute to enhanced methane production from these materials. In the present study, the effects of six different pre-treatments on the hydrolysis and BMP of greaves and rinds, two wastes from pig meat-processing, were evaluated. In a first stage, pre-treatments were performed in closed bottles and the hydrolysates were characterized in terms of COD, LCFA and $\mathrm{NH}_{4}^{+}$. Thereafter, anaerobic biodegradability of the hydrolysates was studied in batch assays and compared with the BMP of the untreated wastes. The amount of substrate added to the anaerobic bottle was based on LCFA and $\mathrm{NH}_{4}^{+}$concentrations in the hydrolysates.

\section{Methods}

\subsection{Meat-processing wastes}

Two wastes from a meat-processing plant located in Portugal were used: (i) greaves, the residue that remains after the rendering of pig tallow, and (ii) rinds, the tough outer covering of bacon or pig meat. The materials were reduced to small particles less than 3-5 $\mathrm{mm}$ in size in the factory and stored at $-20^{\circ} \mathrm{C}$. Total and volatile solids (TS and VS), total Kjeldahl nitrogen (TKN), total phosphorus, fats and free long-chain fatty acids (LCFA) were determined after freeze-drying. Protein content was calculated from the TKN value using a conversion factor of 6.25 (Salminen et al., 2000). Total theoretical COD was calculated by applying stoichiometric conversion factors, i.e. 1.50 and $2.87 \mathrm{~g} \mathrm{COD} \mathrm{g}^{-1}$ for proteins and lipids, respectively (Palatsi et al., 2011). The characteristics of the studied materials are presented in Table 2.

Table 2

Characterisation of greaves and rinds (average values and their standard deviation are presented).

\begin{tabular}{lll}
\hline Parameter & Greaves & Rinds \\
\hline Color & Brownish & Whitish \\
Total solids (\%) & $88 \pm 0$ & $65 \pm 2$ \\
Volatile solids (\%) & $86 \pm 0$ & $65 \pm 2$ \\
Total theoretical COD $\left(\mathrm{g} \mathrm{kg}^{-1}\right)^{\mathrm{a}}$ & 1846 & 1774 \\
TKN $\left(\mathrm{g} \mathrm{kg}^{-1}\right)$ & $70 \pm 2$ & $73 \pm 15$ \\
Total phosphorus $\left(\mathrm{g} \mathrm{kg}^{-1}\right)$ & 0.6 & 0.3 \\
Proteins $\left(\mathrm{g} \mathrm{kg}^{-1}\right)^{\mathrm{a}}$ & $440 \pm 15$ & $458 \pm 95$ \\
Fats $\left(\mathrm{g} \mathrm{kg}^{-1}\right)$ & $406 \pm 4$ & $379 \pm 80$ \\
Free LCFA $\left(\mathrm{g} \mathrm{kg}^{-1}\right)$ & $23 \pm 1$ & $32 \pm 1$ \\
Oleate $(\mathrm{C} 18: 1)(\%)$ & $41 \pm 2$ & $38 \pm 2$ \\
Stearate $(\mathrm{C} 18: 0)(\%)$ & $30 \pm 4$ & $12 \pm 0$ \\
Palmitate $(\mathrm{C} 16: 0)(\%)$ & $29 \pm 2$ & $42 \pm 3$
\end{tabular}

a Calculated as described in Section 2.1. 


\subsection{Pre-treatments}

Six pre-treatments were tested and the conditions are summarized in Table 3. A 24-h contact period was applied in all the pretreatments, except the ones performed in the autoclave. All the pre-treatments were performed in closed bottles to avoid the loss of ammonia to the atmosphere. Before opening the bottles, the $\mathrm{pH}$ was adjusted to neutral values with $8 \mathrm{~N} \mathrm{HCl}$.

The lipase from Candida rugosa (Sigma, $20 \mathrm{U} \mathrm{mg}^{-1}$ ) was dissolved in $0.1 \mathrm{M}$ sodium phosphate buffer solution $(\mathrm{pH} 7.3)$ and mixed with the wastes at a final activity of $10 \mathrm{U} \mathrm{g}^{-1}$ fat (Jeganathan et al., 2007), corresponding to an enzyme/waste ratio of $0.02 \%(\mathrm{w} /$ $\mathrm{w})$. One enzyme unit (U) was defined as the amount of enzyme that liberates $1 \mu \mathrm{mol}$ of free fatty acid per min at $\mathrm{pH} 7.2$ and $37^{\circ} \mathrm{C}$. Hydrolysis was performed at $37^{\circ} \mathrm{C}$, with gentle agitation, for $24 \mathrm{~h}$, after which the enzyme was denatured in a water batch at $60{ }^{\circ} \mathrm{C}$ for $15 \mathrm{~min}$. In the autoclaving + enzyme pre-treatment (AE), wastes were heat-treated at $121^{\circ} \mathrm{C}$ for $20 \mathrm{~min}$ prior to addition of the enzyme.

After the pre-treatments, soluble + colloidal COD and free LCFA were analyzed in the liquid fractions. Ammonium concentrations were quantified for all the hydrolysates, except the ones resulting from the treatment with lipase (E and $\mathrm{AE}$ ).

\subsection{Anaerobic biodegradability assays}

Anaerobic biodegradability of the untreated and treated wastes (hydrolysates) was studied in batch assays. Granular sludge from a brewery wastewater treatment plant was used as inoculum, with a specific methanogenic activity of $53 \pm 3$ and $508 \pm$ $105 \mathrm{~mL} \mathrm{CH}_{4 @ S T P} \mathrm{~g}^{-1} \mathrm{VS} \mathrm{day}^{-1}$ in the presence of acetate and $\mathrm{H}_{2} /$ $\mathrm{CO}_{2}$, respectively. Anaerobic basal medium was prepared as described by Angelidaki et al. (2009) and transferred to 160-mL bottles ( $80 \mathrm{~mL}$ working volume) already containing substrate and inoculum at a final concentration of $8 \mathrm{~g} \mathrm{VS} \mathrm{L}^{-1}$. For untreated wastes, an inoculum:substrate ratio of $4 \mathrm{~g} \mathrm{VS}_{\text {inoculum }} \mathrm{g}^{-1} \mathrm{COD}_{\text {total }}$ was used. For the hydrolysates, different amounts were added to each bottle, considering the free LCFA concentrations determined after pretreatments, and a maximum threshold concentration of $0.5 \mathrm{~g}$ COD-free LCFA g ${ }^{-1} \mathrm{VS}_{\text {inoculum. This value was based on the kinetics }}$ proposed by Pereira et al. (2004), who found that specific LCFA contents above $1 \mathrm{~g}$ COD-free LCFA g ${ }^{-1} \mathrm{VS}_{\text {inoculum }}$ decreased the capacity of the anaerobic microorganisms to produce methane from LCFA. Therefore, $4 \mathrm{~g} \mathrm{VS}_{\text {inoculum }} \mathrm{g}^{-1} \mathrm{COD}_{\text {soluble+colloidal }}$ and $1.3-3.3 \mathrm{~g}$ $\mathrm{VS}_{\text {inoculum }} \mathrm{g}^{-1} \mathrm{COD}_{\text {total }}$ were applied in the bottles amended with the hydrolysates. $\mathrm{N}-\mathrm{NH}_{4}^{+}$concentrations were lower than $25 \mathrm{mg} \mathrm{L}^{-1}$. Bottles were sealed with butyl rubber septa and aluminum screw caps, and the headspace was flushed with a mixture of $\mathrm{N}_{2} / \mathrm{CO}_{2}(80: 20 \mathrm{v} / \mathrm{v})$. Sodium sulphide was added as reducing agent, to a final maximum concentration of $1 \mathrm{mM}$. Blank assays (without substrate) were prepared in a similar way. All the tests were performed in triplicate and incubated at $37^{\circ} \mathrm{C}, 150 \mathrm{rpm}$, under strict anaerobic conditions.
Methane content of the accumulated biogas was periodically measured by gas chromatography, and the methane production values were corrected for standard temperature and pressure (STP) conditions. BMP values were expressed per VS of the original waste, i.e. the cumulative methane production obtained at the end of the biodegradability tests (after subtraction of the value obtained in the blank assays) was divided by the equivalent VS content of the amount of waste that was pre-treated and transferred to the biodegradability tests. To compare the BMP values obtained with the theoretical potentials of the raw wastes, methane recovery (\%) was calculated for the different conditions studied (Eq. (1)):

$$
\mathrm{CH}_{4} \text { recovery }(\%)=\frac{B M P \times 100}{\text { Theoretical } \left.\mathrm{CH}_{4} \text { potential (raw waste }\right)}
$$

The theoretical methane potential of the wastes (greaves or rinds) was calculated considering its physico-chemical characterization (Table 2) and the following theoretical values of methane production: $0.63 \mathrm{~L} \mathrm{CH}_{4} \mathrm{~g}^{-1}$ protein and $0.99 \mathrm{~L} \mathrm{CH}_{4} \mathrm{~g}^{-1}$ lipid at STP conditions (Li et al., 2002). In the assays prepared with the enzymatic hydrolysates ( $\mathrm{E}$ and $\mathrm{AE}$ ), the potential methane production from the degradation of the inactivated enzyme was less than $0.1 \mathrm{~mL}$ methane at STP conditions. Therefore, it was considered irrelevant.

At the end of the biodegradability assays, samples from the liquid medium were analyzed for soluble + colloidal COD, volatile fatty acids (VFA), free LCFA and ammonium. The maximum theoretical amount of sodium chloride that could be present in the bottles prepared with the alkaline hydrolysates was always lower than $3.6 \mathrm{~g} \mathrm{~L}^{-1}$.

\subsection{Analytical methods}

Solids (TS and VS), COD, TKN, ammonium and fats were measured according to standard methods (APHA et al., 1989). Soluble + colloidal COD was determined after centrifugation of the sample at $22,000 \mathrm{~g}$ for $15 \mathrm{~min}$. Total phosphorus was quantified using standard kits (Hach Lange, Düsseldorf, Germany). LCFA quantification was performed as described by Neves et al. (2009). Briefly, esterification and extraction of free fatty acids was performed with a mixture of propanol, $\mathrm{HCl}$ and dichloromethane, for $3.5 \mathrm{~h}$ at $100^{\circ} \mathrm{C}$. The extracts were analyzed by gas chromatography (Varian 3800, flame ionization detector, Teknokroma TR-WAX eq. CP-Sil 52 CB $30 \mathrm{~m} \times 0.32 \mathrm{~mm} \times 0.25 \mu \mathrm{m}$ capillary column). Helium was used as carrier gas at a flow rate of $1.0 \mathrm{~mL} \mathrm{~min}^{-1}$. Initial oven temperature was set at $50^{\circ} \mathrm{C}$ for 2 min and the final temperature of $225^{\circ} \mathrm{C}$ was attained with a ramp rate of $10^{\circ} \mathrm{C} \mathrm{min}{ }^{-1}$. Injector and detector temperatures were $220^{\circ} \mathrm{C}$ and $250^{\circ} \mathrm{C}$, respectively. VFA were determined by HPLC (Jasco, Japan), using a Chrompack organic acids analysis column $(30 \times 6.5 \mathrm{~mm})$ and a mobile phase of $5 \mathrm{mM} \mathrm{H}_{2} \mathrm{SO}_{4}$ at a flow rate of $0.6 \mathrm{~mL} \mathrm{~min}^{-1}$. The column was set at $60^{\circ} \mathrm{C}$, and the detection was made spectrophotometrically at $210 \mathrm{~nm}$. The methane content of the accumulated biogas was measured in a Micro-GC CP-4900 (Varian Inc.). A 10-m PPU column was

Table 3

Pre-treatment conditions applied.

\begin{tabular}{|c|c|c|c|c|c|c|}
\hline Pre-treatment & Code & $\mathrm{NaOH}$ & Temperature & Enzyme & Time & Equipment \\
\hline Base & B & $0.3 \mathrm{~g} \mathrm{~g}^{-1} \mathrm{TS}^{\mathrm{a}}$ & $25^{\circ} \mathrm{C}$ & - & $24 \mathrm{~h}$ & - \\
\hline Base + temperature & BT & $0.3 \mathrm{~g} \mathrm{~g}^{-1} \mathrm{TS}^{\mathrm{a}}$ & $55^{\circ} \mathrm{C}$ & - & $24 \mathrm{~h}$ & Water bath \\
\hline Base + autoclaving & BA & $0.3 \mathrm{~g} \mathrm{~g}^{-1} \mathrm{TS}^{\mathrm{a}}$ & $121^{\circ} \mathrm{C}$ & - & $20 \mathrm{~min}$ & Autoclave \\
\hline Temperature & $\mathrm{T}$ & - & $70^{\circ} \mathrm{C}$ & - & $24 \mathrm{~h}$ & Oven \\
\hline Enzyme & $\mathrm{E}$ & - & $37^{\circ} \mathrm{C}$ & $10 \mathrm{U} \mathrm{g}^{-1} \mathrm{fat}^{\mathrm{b}}$ & $24 \mathrm{~h}$ & - \\
\hline Autoclaving + enzyme & $\mathrm{AE}$ & - & $121^{\circ} \mathrm{C} / 37^{\circ} \mathrm{C}$ & $10 \mathrm{Ug}^{-1} \mathrm{fat}^{\mathrm{b}}$ & $20 \mathrm{~min} / 24 \mathrm{~h}$ & Autoclave \\
\hline
\end{tabular}

${ }^{a}$ Based on the work of Neves et al. (2006).

b $\mathrm{U}=$ enzyme unit. This value is based on the work of Jeganathan et al. (2007). 
heated at $80^{\circ} \mathrm{C}$ and helium (at $150 \mathrm{kPa}$ ) was used as carrier gas. The temperature of the thermal conductivity detector and injection port was 55 and $110^{\circ} \mathrm{C}$, respectively.

\subsection{Statistical analysis}

The statistical significance of the differences detected in the BMP values was evaluated using single factor analysis of variances (ANOVA). Statistical significance was established at $P<0.05$.

\section{Results}

\subsection{Effects of the different pre-treatments}

The use of physical, chemical and enzymatic methods to pretreat greaves and rinds produced hydrolysates with different characteristics, as shown by the soluble + colloidal COD, free LCFA and $\mathrm{NH}_{4}^{+}$concentrations (Table 4).

A maximum value of $1220 \mathrm{~g} \mathrm{COD}_{\text {sol+coll }} \mathrm{kg}^{-1}$ raw waste was obtained for greaves with the combined action of base and temperature (BT), although high concentrations around $1000 \mathrm{~g} \mathrm{COD}_{\text {sol+coll }} \mathrm{kg}^{-1}$ raw waste were also accomplished with enzymatic pre-treatments ( $\mathrm{E}$ and $\mathrm{AE}$ ). For rinds, maximum values of 900-1000 $\mathrm{g} \mathrm{COD}_{\text {sol+coll }} \mathrm{kg}^{-1}$ were obtained with base and autoclaving + enzyme addition (Table 4). The highest percentage of fat hydrolysis (52-54\%) occurred for the pre-treatment of greaves with base + temperature (BT) and for the pre-treatment of rinds with base alone (B). The free LCFA concentrations were around $188 \mathrm{~g}$ free LCFA $\mathrm{kg}^{-1}$ raw waste. The $C$. rugosa lipase only achieved $26-33 \%$ of fat hydrolysis in both wastes (Table 4 ). In all cases, oleate (C18:1) and palmitate (C16:0) were the most abundant LCFAs released during the hydrolysis of lipids, accounting for $30-50 \%$ and $15-35 \%$ of the free LCFAs, respectively.

\subsection{Anaerobic biodegradability assays}

A potential methane production of 794 and $1028 \mathrm{~L} \mathrm{CH}_{4 @ S T P} \mathrm{~kg}^{-1}$ VS was calculated for raw greaves and rinds, respectively, based on the lipid and protein contents of the wastes (Table 2), and on theoretical values of methane production from these macromolecules, as described in Section 2.3. The BMP values calculated at the end of the biodegradability assays for the raw and treated wastes are compiled in Table 5. By comparing these BMP values with the theoretical potential of the untreated wastes, methane recovery was calculated for the different conditions studied (Eq. (1), Table 5).

\subsubsection{Anaerobic biodegradability of greaves}

In bottles amended with untreated greaves, methane production accounted for $89 \%$ of the maximum potential value
( $\left.\mathrm{BMP}=707 \pm 46 \mathrm{~L} \mathrm{CH}_{4 @ S T P} \mathrm{~kg}^{-1} \mathrm{VS}\right)$, showing good biodegradability of the raw waste (Table 5). Pre-treating the greaves did not improve BMP values and imposing temperatures between $55-121{ }^{\circ} \mathrm{C}$ (in treatments BT, BA and T) even decreased the methane recovered by $36-57 \%$ (Table 5). Moreover, none of the strategies tested was able to improve the methane production rate, as shown by the slope of the cumulative methane production curves in Fig. 1.

Results of the analysis performed in the mixed liquor content of the vials at the end of the biodegradability tests are presented in Table 5. In all the assays amended with untreated and treated greaves, VFA and LCFA did not accumulate, whereas concentrations higher than $390 \mathrm{mg} \mathrm{N}-\mathrm{NH}_{4}^{+} \mathrm{L}^{-1}$ where measured. Digestion of untreated greaves generated $934 \pm 43 \mathrm{mg} \mathrm{N}-\mathrm{NH}_{4}^{+} \mathrm{L}^{-1}$, and this value was only exceeded in the assays amended with hydrolysates produced by heat-treatment $(\mathrm{T})$.

\subsubsection{Anaerobic biodegradability of rinds}

In the assay prepared with untreated rinds, a maximum cumulative methane production of $756 \pm 56 \mathrm{~L} \mathrm{CH}_{4 @ S T P} \mathrm{~kg}^{-1} \mathrm{VS}$ was achieved after approximately 30 days of incubation, corresponding to $74 \pm 5 \%$ of the maximum potential value for this waste (Table 5 , Fig. 2).

A 25\% higher BPM value was obtained in assays amended with rinds pre-treated with heat (Table 5, Fig. 2). In the other situations, BMP was not significantly different (AE treatment) or was lower (B, BT, BA and E) than that of untreated waste. Anaerobic biodegradability of B- and BT-treated rinds was severely reduced, since methane production in these assays was lower than that of the blanks (where approximately $60 \mathrm{mLCH}_{4 @ S T P}$ was measured). Methane production rate was not improved by any of the strategies applied (Fig. 2).

VFA and free LCFA concentrations around $3500 \mathrm{mg} \mathrm{L}^{-1}$ and 1000-1500 $\mathrm{mg} \mathrm{L}^{-1}$, respectively, were observed at the end of the experiment in bottles amended with physical-chemical hydrolysates, although these intermediary compounds were not detected after anaerobic degradation of enzymatic hydrolysates (E and $\mathrm{AE}$ ) or of untreated waste. Acetic and $n$-butyric acids were the major VFAs, accounting for approximately $50 \%$ and $30 \%$ of total VFA, respectively; palmitate represented $40-68 \%$ of the total free LCFAs measured. Ammonium was present in all the vials at concentrations higher than $345 \mathrm{mg} \mathrm{N}-\mathrm{NH}_{4}^{+} \mathrm{L}^{-1}$, reaching maximum values of around $1000 \mathrm{mg} \mathrm{N}-\mathrm{NH}_{4}^{+} \mathrm{L}^{-1}$ in the $\mathrm{B}, \mathrm{BT}$ and $\mathrm{T}$ treatments (Table 5).

\section{Discussion}

Greaves and rinds are produced during pig meat-processing operations and have a very low or even no market value. Mainly composed of fats and proteins, these materials present a high potential for methane production, i.e. 794 and $1028 \mathrm{~L} \mathrm{CH}_{4 @ S T P} \mathrm{~kg}^{-1} \mathrm{VS}$

Table 4

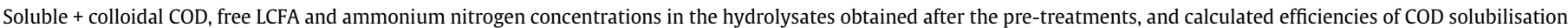
$\left(E_{\mathrm{COD}}\right)$ and fat hydrolysis $\left(\mathrm{E}_{\mathrm{fats}}\right)$. Data are average values and their standard deviations, calculated from triplicate measurements.

\begin{tabular}{|c|c|c|c|c|c|c|}
\hline Waste & Pre-treatment & $\mathrm{COD}_{\text {sol+coll }}\left(\mathrm{g} \mathrm{kg}^{-1} \mathrm{RW}\right)$ & $\mathrm{E}_{\mathrm{COD}}(\%)$ & Free LCFA ( $\left.\mathrm{g} \mathrm{kg}^{-1} \mathrm{RW}\right)$ & $\mathrm{E}_{\text {fats }}(\%)$ & $\mathrm{NH}_{4}^{+}\left(\mathrm{g} \mathrm{N} \mathrm{kg}^{-1} \mathrm{RW}\right)$ \\
\hline \multirow[t]{6}{*}{ Greaves } & Base (B) & 672 & 36 & $42 \pm 0$ & $12 \pm 0$ & $5 \pm 0$ \\
\hline & Base + temperature (BT) & 1220 & 66 & $188 \pm 126$ & $52 \pm 3$ & $8 \pm 0$ \\
\hline & Base + autoclaving (BA) & $532 \pm 13$ & $29 \pm 1$ & $31 \pm 5$ & $8 \pm 1$ & n.d. \\
\hline & Temperature $(\mathrm{T})$ & 520 & 28 & $30 \pm 10$ & $8 \pm 3$ & $3 \pm 0$ \\
\hline & Enzyme (E) & $1115 \pm 13$ & $60 \pm 1$ & $103 \pm 4$ & $28 \pm 1$ & n.d. \\
\hline & Autoclaving + enzyme (AE) & $981 \pm 1$ & $53 \pm 0$ & $95 \pm 3$ & $26 \pm 1$ & n.d. \\
\hline \multirow[t]{6}{*}{ Rinds } & Base (B) & 896 & 50 & $183 \pm 0$ & $54 \pm 16$ & $1 \pm 0$ \\
\hline & Base + temperature (BT) & 504 & 28 & $127 \pm 0$ & $37 \pm 1$ & $3 \pm 0$ \\
\hline & Base + autoclaving (BA) & $550 \pm 2$ & $31 \pm 0$ & $41 \pm 7$ & $12 \pm 2$ & n.d. \\
\hline & Temperature $(\mathrm{T})$ & 578 & 33 & $62 \pm 0$ & $18 \pm 7$ & $1 \pm 0$ \\
\hline & Enzyme (E) & $634 \pm 8$ & $36 \pm 1$ & $91 \pm 4$ & $27 \pm 1$ & n.d. \\
\hline & Autoclaving + enzyme (AE) & $984 \pm 4$ & $55 \pm 0$ & $111 \pm 11$ & $33 \pm 3$ & n.d. \\
\hline
\end{tabular}

RW = raw waste. n.d. - not determined. 
Table 5

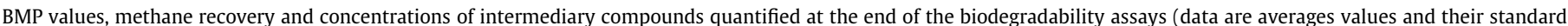
deviations, calculated from triplicate measurements).

\begin{tabular}{|c|c|c|c|c|c|c|}
\hline Waste & Pre-treatment & $\mathrm{BMP}\left(\mathrm{LCH}_{4 @ S T P} \mathrm{~kg}^{-1} \mathrm{VS}\right)^{\mathrm{a}}$ & $\mathrm{CH}_{4}$ recovery $(\%)^{\mathrm{b}}$ & LCFA $\left(\mathrm{mg} \mathrm{L}^{-1}\right)$ & $\mathrm{VFA}\left(\mathrm{mg} \mathrm{L}^{-1}\right)$ & $\mathrm{NH}_{4}^{+}\left(\mathrm{mg} \mathrm{N} \mathrm{L}^{-1}\right)$ \\
\hline \multirow[t]{7}{*}{ Greaves } & Raw waste (RW) & $707 \pm 46$ & $89 \pm 6$ & 233 & 0 & $934 \pm 43$ \\
\hline & Base (B) & $630 \pm 108$ & $79 \pm 14$ & 0 & 0 & $925 \pm 0$ \\
\hline & Base + temperature (BT) & $453 \pm 77$ & $57 \pm 10$ & 0 & 0 & $897 \pm 112$ \\
\hline & Base + autoclaving (BA) & $305 \pm 21$ & $38 \pm 3$ & 0 & n.d. & $392 \pm 49$ \\
\hline & Temperature $(\mathrm{T})$ & $414 \pm 84$ & $52 \pm 11$ & 0 & 0 & $1289 \pm 28$ \\
\hline & Enzyme (E) & $641 \pm 36$ & $81 \pm 5$ & 0 & 0 & $402 \pm 58$ \\
\hline & Autoclaving + enzyme (AE) & $662 \pm 53$ & $83 \pm 7$ & 0 & 0 & $411 \pm 16$ \\
\hline \multirow[t]{7}{*}{ Rinds } & Raw waste (RW) & $756 \pm 56$ & $74 \pm 5$ & 0 & 0 & $878 \pm 144$ \\
\hline & Base (B) & c & c & 1152 & 3645 & $915 \pm 58$ \\
\hline & Base + temperature (BT) & c & c & 1192 & 3411 & $1023 \pm 99$ \\
\hline & Base + autoclaving (BA) & 533 & 52 & 1487 & n.d. & $364 \pm 49$ \\
\hline & Temperature $(\mathrm{T})$ & $941 \pm 57$ & $92 \pm 6$ & $129 \pm 100$ & 69 & $1196 \pm 16$ \\
\hline & Enzyme (E) & $609 \pm 34$ & $59 \pm 3$ & 0 & 0 & $430 \pm 16$ \\
\hline & Autoclaving + enzyme (AE) & $919 \pm 223$ & $89 \pm 22$ & 0 & 0 & $346 \pm 16$ \\
\hline
\end{tabular}

${ }^{a}$ L methane per kg VS of raw waste (as described in Section 2.3).

b Calculated relatively to the theoretical methane production of the wastes (as described in Section 2.3).

c Methane production in these assays was lower than the value obtained in blank assays.
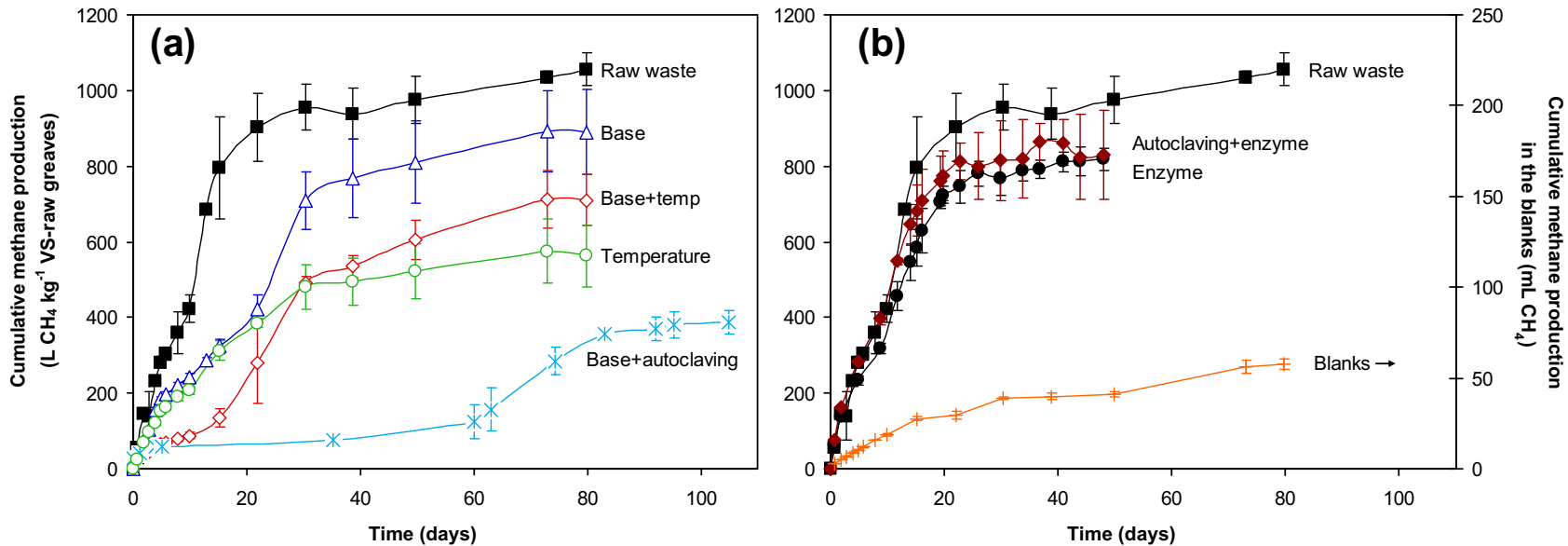

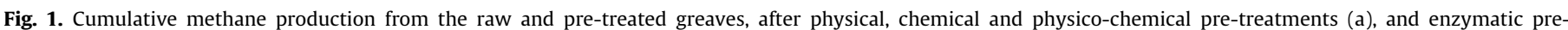

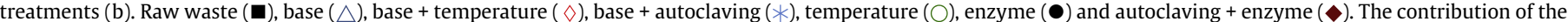
blank was not subtracted in these curves, and is presented $(+)$ in (b). Error bars represent standard deviations of triplicate measurements.
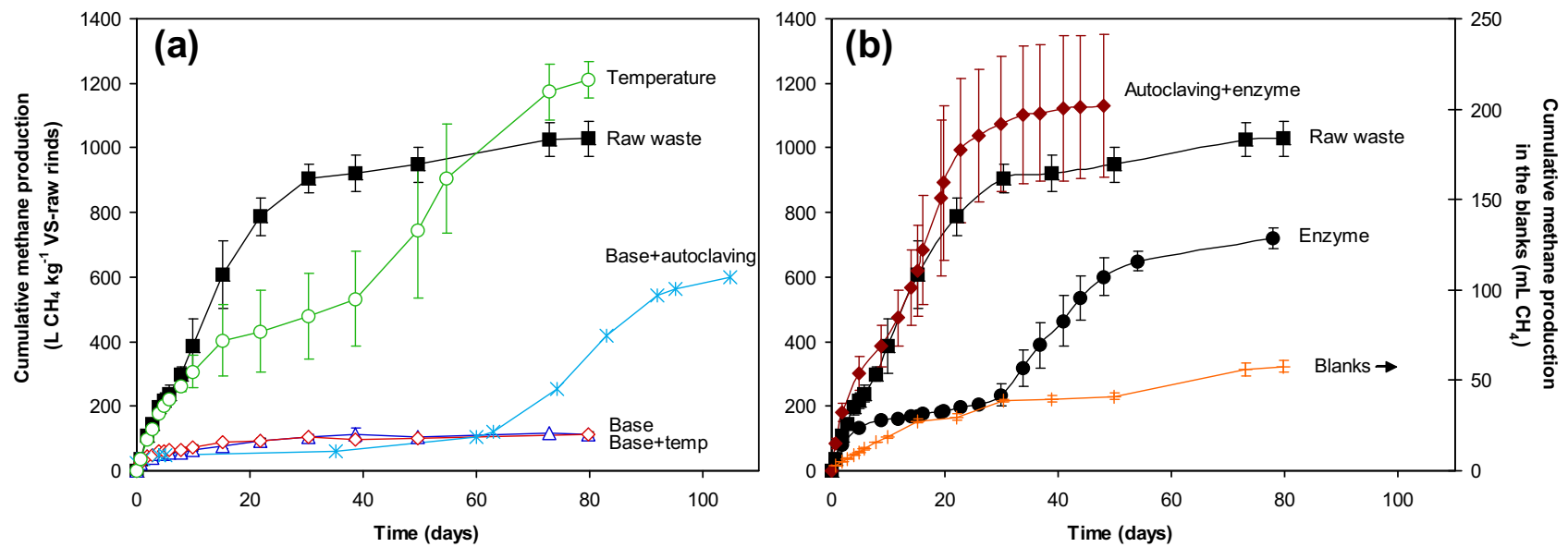

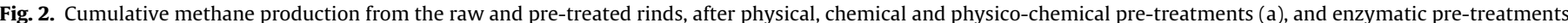

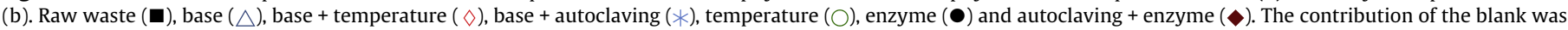
not subtracted in these curves, and is presented $(+)$ in (b). Error bars represent standard deviations of triplicate measurements. 
can be expected from the anaerobic biodegradation of greaves and rinds, respectively. In practice, BMP values of $707 \pm 46 \mathrm{~L} \mathrm{CH}_{4 @ \text { @TP }}$ $\mathrm{kg}^{-1}$ VS-greaves and $756 \pm 56 \mathrm{~L} \mathrm{CH}_{4 @ S T P} \mathrm{~kg}^{-1} \mathrm{VS}$-rinds were obtained in the biodegradability tests, corresponding to $89 \pm 6 \%$ and $74 \pm 5 \%$ of the calculated theoretical methane potentials, respectively. These values, and the absence of a lag phase in the methane production curves (Figs. 1 and 2), show good biodegradability of the raw wastes, with greaves being slightly more biodegradable at anaerobic conditions than rinds.

However, despite the good biodegradability of the wastes, methane production rates were low, since maximum cumulative methane production was only attained after approx. 30 days of incubation. Therefore, pre-treatment of the organic materials prior to the anaerobic digestion was used as a possible strategy to accelerate methane production rates and eventually increase wastes biodegradability even further.

Of the different strategies tested, alkaline treatments appear to be the best for improving hydrolysis of the organic materials. Treatments performed with $\mathrm{NaOH}$ (at $25^{\circ} \mathrm{C}$ or $55^{\circ} \mathrm{C}$ ) yielded high soluble + colloidal COD concentrations and simultaneously stimulated the hydrolysis of fats (Table 4). Nevertheless, the positive effects of $\mathrm{NaOH}$ were not intensified by the 20-min application of $121^{\circ} \mathrm{C}$ and $138 \mathrm{kPa}$ imposed in the autoclave.

Enzymatic treatments only released $26-33 \%$ of the LCFA present in the wastes. Difficult access of the enzymes to the substrates or inadequate hydrolysis conditions may have limited the efficacy of this approach.

Although non-inhibitory concentrations of free LCFA and $\mathrm{NH}_{4}^{+}$ were assured at the start of the biodegradability assays, and $\mathrm{NaCl}$ and $\mathrm{Na}^{+}$concentrations in the assays amended with alkalinetreated substrates were non-inhibitory (3.6 and $1.4 \mathrm{~g} \mathrm{~L}^{-1}$, respectively) (de Baere et al., 1984; Rinzema et al., 1988; Zhang and Jahng, 2010), BMP was only significantly increased (25\%, $p<0.0002$ ) when rinds where exposed to a temperature of $70^{\circ} \mathrm{C}$ (Table 5). Reduced BMP were especially observed in the assays amended with rinds pre-treated with base or base + temperature (Table 5, Figs. 1 and 2). Although hydrolysis was incomplete, the pre-treatments may have promoted a faster release of the remaining hydrolysis products in the biodegradability batch assays in comparison with the raw waste BMP assays. Ammonia accumulation was not likely inhibitory since a maximum concentration of $20 \mathrm{mg} \mathrm{N}-\mathrm{NH}_{3} \mathrm{~L}^{-1}$ (pH approx. 7.2) was calculated from the $\mathrm{NH}_{4}^{+}$ values in the mixed liquor at the end of these assays (Table 5). This value is much lower than the inhibitory concentrations reported

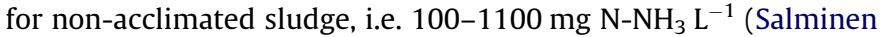
and Rintala, 2002). LCFA and VFA accumulation were probably the reason for the lower BMP values (Table 5). Palmitate was the major LCFA measured, accounting for $40-68 \%$ of the total free LCFA. Palmitate accumulation in lipid/LCFA-inhibited anaerobic digestion processes has been previously reported (Pereira et al., 2002) and shows that $\beta$-oxidation reactions are impaired. This fact is indicative of unbalanced syntrophic relations between LCFA-degrading bacteria and methanogenic archaea. Acetic and butyric acids were the main VFA detected, and total VFA concentrations exceeded $3000 \mathrm{mg} \mathrm{L}^{-1}$, which has been suggested as the threshold value for methanogenic toxicity (Ahring et al., 1995). Pre-treatment could have promoted the fast build-up of LCFA and VFA, causing inhibition of methanogenesis. In this case, the use of an inoculum adapted to lipids could have decreased or avoided inhibition, and accelerated wastes conversion to methane. In the thermal pre-treatment of rinds, the higher BMP was likely due to a slower release of LCFA and VFA in the anaerobic batch test, allowing a slow but steady conversion to methane. The lower hydrolysis efficiency in this case, could be one of the reasons for this behaviour.

In the anaerobic assays amended with hydrolysates of pretreated greaves, LCFA and VFA were not detected at the end of the experiments, despite the fact that methane yields and methane production rates were lower than those obtained with untreated greaves. These observations suggest that methanogenesis was not the rate-limiting step; instead, hydrolysis appears to be the limiting step, even after all the pre-treatments applied. None of the pre-treatments improved the methane production rate from both wastes, and more than 30 days were needed to achieve the plateau in the cumulative methane production (Figs. 1 and 2).

Optimization of the pre-treatment conditions (e.g. different concentration of hydrolysing agents or contact times), or alternative strategies, as the addition of enzyme mixtures or bioaugmentation with enzyme-producing microorganisms, can be tested as future strategies for improving BMP and methane production rates of this type of waste. Considering the high cost of enzymes and the better tolerance of microorganisms to changes in environmental conditions, bioaugmentation is a possible option. In that case lipolytic and proteolytic microorganisms may also be combined with bioaugmentation of LCFA-degrading bacteria to improve the overall process.

\section{Conclusions}

Pre-treating greaves and rinds with physical, chemical and enzymatic methods did not improve wastes conversion to methane and, in some cases, BMP were lower than those of untreated wastes. For rinds, this was possibly due to an improved accessibility of the treated materials to anaerobic microorganisms. LCFA and VFA accumulated in the batch vials and inhibited methanogenesis. For greaves, hydrolysis was the limiting step even after pretreatment. Further studies are necessary to increase hydrolysis efficiency and to optimize the ultimate methane production from this type of meat-processing wastes.

\section{Acknowledgements}

The authors thank Cristiana Gonçalves for her help with the enzymatic pre-treatments. The financial support from Portuguese Innovation Agency (ADI), through the project FatValue (QREN no. 3491), is gratefully acknowledged. Professor Giovana Tommaso thanks the EMUNDUS15 - Erasmus Mundus External Cooperation Window (Lot15) that provided financial support for her stay in the University of Minho, Portugal.

\section{References}

Ahring, B.K., Sandberg, M., Angelidaki, I., 1995. Volatile fatty acids as indicators of process imbalance in anaerobic digesters. Appl. Microbiol. Biotechnol. 43 (3), 559-565.

Alves, M.M., Pereira, M.A., Sousa, D.Z., Cavaleiro, A.J., Picavet, M., Smidt, H., Stams A.J.M., 2009. Waste lipids to energy: how to optimize methane production from long-chain fatty acids (LCFA). Microb. Biotechnol. 2 (5), 538-550.

Angelidaki, I., Alves, M., Bolzonella, D., Borzacconi, L., Campo, J.L., Guwy, A.J., Kalyuzhnyi, S., Jenicek, P., van Lier, J.B., 2009. Defining the biomethane potential (BMP) of solid organic wastes and energy crops: a proposed protocol for batch assays. Water Sci. Technol. 59 (5), 927-934.

APHA, AWWA, WPCF, 1989. Standard Methods for the Examination of Water and Wastewater, seventeenth ed. American Public Health Association, Washington, DC

Battimelli, A., Carrère, H., Delgenès, J.P., 2009. Saponification of fatty slaughterhouse wastes for enhancing anaerobic biodegradability. Bioresour. Technol. 100 (15), 3695-3700.

Battimelli, A., Torrijos, M., Molleta, R., Delgenès, J.P., 2010. Slaughterhouse fatty waste saponification to increase biogas yield. Bioresour. Technol. 101 (10), 3388-3393.

Bougrier, C., Delgenès, J.P., Carrère, H., 2008. Effects of thermal treatments on five different waste activated sludge samples solubilisation, physical properties and anaerobic digestion. Chem. Eng. J. 139 (2), 236-244.

Cammarota, M.C., Freire, D.M.G., 2006. A review on hydrolytic enzymes in the treatment of wastewater with high oil and grease content. Bioresour. Technol. 97 (17), 2195-2210. 
Carrère, H., Dumas, C., Battimelli, A., Batstone, D.J., Delgenès, J.P., Steyer, J.P., Ferrer, I., 2010. Pretreatment methods to improve sludge anaerobic degradability: a review. J. Hazard. Mater. 183 (1-3), 1-15.

Cavaleiro, A.J., Pereira, M.A., Alves, M.M., 2008. Enhancement of methane production from long chain fatty acid based effluents. Bioresour. Technol. 99, 4086-4095.

Costa, J.C., Barbosa, S.G., Alves, M.M., Sousa, D.Z., 2012. Thermochemical pre- and biological co-treatments to improve hydrolysis and methane production from poultry litter. Bioresour. Technol. 111, 141-147.

Cuadros, F., López-Rodríguez, F., Ruiz-Celma, A., Rubiales, F., González-González, A. 2011. Recycling, reuse and energetic valuation of meat industry wastes in Extremadura (Spain). Resour. Conserv. Recycl. 55 (4), 393-399.

Cuetos, M.J., Gómez, X., Otero, M., Morán, A., 2010. Anaerobic digestion and codigestion of slaughterhouse waste (SHW): influence of heat and pressure pretreatment in biogas yield. Waste Manage. (Oxford) 30 (10), 1780-1789.

de Baere, L.A., Devocht, M., Van Assche, P., Verstraete, W., 1984. Influence of high $\mathrm{NaCl}$ and $\mathrm{NH}_{4} \mathrm{Cl}$ salt levels on methanogenic associations. Water Res. 18 (5), 543-548.

FAOSTAT. Food and Agriculture Organization of the United Nations (ProdSTAT data domain): <http://faostat.fao.org/site/569/default.aspx\#ancor> [Accessed January 11st 2012].

Hejnfelt, A., Angelidaki, I., 2009. Anaerobic digestion of slaughterhouse by-products. Biomass Bioenergy 33 (8), 1046-1054.

Jeganathan, J., Nakhla, G., Bassi, A., 2007. Oily wastewater treatment using a novel hybrid PBR-UASB system. Chemosphere 67 (8), 1492-1501.

Kadam, P.C., Boone, D.R., 1996. Influence of $\mathrm{pH}$ on ammonia accumulation and toxicity in halophilic, methylotrophic methanogens. Appl. Environ. Microbiol. 62 (12), 4486-4492.

Li, Y.Y., Sasaki, H., Yamashita, K., Seki, K., Kamigochi, I., 2002. High-rate methane fermentation of lipid-rich food wastes by a high-solids co-digestion process. Water Sci. Technol. 45 (12), 143-150.

Luste, S., Luostarinen, S., Sillanpää, M., 2009. Effect of pre-treatments on hydrolysis and methane production potentials of by-products from meat-processing industry. J. Hazard. Mater. 164 (1), 247-255.

Masse, L., Massé, D.I., Kennedy, K.J., 2003. Effect of hydrolysis pretreatment on fat degradation during anaerobic digestion of slaughterhouse wastewater. Process Biochem. 38 (9), 1365-1372.
Neves, L., Ribeiro, R., Oliveira, R., Alves, M.M., 2006. Enhancement of methane production from barley waste. Biomass Bioenergy 30 (6), 599-603.

Neves, L., Pereira, M.A., Mota, M., Alves, M.M., 2009. Detection and quantification of long chain fatty acids in liquid and solid samples and its relevance to understand anaerobic digestion of lipids. Bioresour. Technol. 100 (1), 91-96.

Palatsi, J., Vinas, M., Guivernau, M., Fernandez, B., Flotats, X., 2011. Anaerobic digestion of slaughterhouse waste: main process limitations and microbial community interactions. Bioresour. Technol. 102 (3), 2219-2227.

Pereira, M.A., Pires, O.C., Mota, M., Alves, M.M., 2002. Anaerobic degradation of oleic acid by suspended and granular sludge: identification of palmitic acid as a key intermediate. Water Sci. Technol. 45 (10), 139-144.

Pereira, M.A., Pires, O.C., Mota, M., Alves, M.M., 2005. Anaerobic biodegradation of oleic and palmitic acids: evidence of mass transfer limitations caused by long chain fatty acid accumulation onto the anaerobic sludge. Biotechnol. Bioeng. 92 (1), 15-23.

Pereira, M.A., Sousa, D.Z., Mota, M., Alves, M.M., 2004. Mineralization of LCFA associated with anaerobic sludge: kinetics, enhancement of methanogenic activity, and effect of VFA. Biotechnol. Bioeng. 88 (4), 502-511.

Rinzema, A., van Lier, J., Lettinga, G., 1988. Sodium inhibition of acetoclastic methanogens in granular sludge from a UASB reactor. Enzyme Microb. Technol. 10 (1), 24-32.

Salminen, E., Rintala, J., 2002. Anaerobic digestion of organic solid poultry slaughterhouse waste-a review. Bioresour. Technol. 83 (1), 13-26.

Salminen, E., Rintala, J., Lokshina, L.Y., Vavilin, V.A., 2000. Anaerobic batch degradation of solid poultry slaughterhouse waste. Water Sci. Technol. 41 (3), 33-41.

Valladão, A.B.G., Freire, D.M.G., Cammarota, M.C., 2007. Enzymatic pre-hydrolysis applied to the anaerobic treatment of effluents from poultry slaughterhouses. Int. Biodeterior. Biodegrad. 60 (4), 219-225.

Vavilin, V.A., Rytov, S.V., Lokshina, L.Ya., 1996. A description of hydrolysis kinetics in anaerobic degradation of particulate organic matter. Bioresour. Technol. 56, 229-237.

Zhang, L., Jahng, D., 2010. Enhanced anaerobic digestion of piggery wastewater by ammonia stripping: effects of alkali types. J. Hazard. Mater. 182 (1-3), 536-543. 